DOI: $10.2478 /$ lpts-2018-0016

PHYSICAL AND TECHNICAL ENERGY PROBLEMS

\title{
EFFECTIVENESS OF THE TOOTH ZONE OF INDUCTOR ELECTRIC MACHINE
}

\author{
A. Serebryakov, E. Kamolins, K. Gulbis, K. Sejejs \\ Riga Technical University \\ 12/1 Azenes Str., Riga, LV-1048, LATVIA \\ e-mail: edmunds.kamolins@rtu.lv
}

The authors consider several tens of rotor tooth and slot profiles for the inductor electric machine in order to gain the maximum EMF of the armature winding at the minimum of highest harmonics, owing to which the specific power and efficiency of the machine can be raised.

The research considers usage of analytical methodology and finite element method (FEM), where the latter includes magnetic saturation and actual magnetic field line distribution.

The main data of both calculations are summarised in the results of the study. From the obtained results, it can be concluded that, in most cases, the analytical method is not applicable to the qualitative determination of the highest harmonic content of the EMF, since the plane of the magnetic field lines does not close in parallel and their distribution is directly related to the configuration of the teeth zone.

The possibility of using the inductor generators for direct connection to the grid is demonstrated in the study.

Keywords: harmonic distortion, inductor electric machine, tooth shapes

\section{INTRODUCTION}

The inductor electric machines (IEMs) - owing to their simple and reliable design - have received wide recognition in technology - mainly as machines of low and intermediate power (i.e., diesel generators, train car and welding generators, gearless wind generators, phase splitters, etc.). A majority of such machines supply load via an intermediate converter (rectifier, frequency converter, etc.). The main criterion of their operational quality is the value of the armature winding EMF, while the EMF sinusoidal shape, which is determined by the highest harmonic content, serves as a supplementary criterion. 
Serviceability of an IEM is determined by the permeance value and the rate of its changing in the airgap between the teeth of stator and rotor at running of the latter. The value of permeance depends on the variation of the airgap between these teeth, while its rate - on the rotational speed of the rotor. In this process, the magnetic flux through the airgap and the magnetic-flux linkage of the armature winding are changing; as a result, the EMF induced there affects the machine power.

In IEMs of the known design, the magnetic flux pulsating from its maximum value to the minimum one also contains - apart from a variable component that determines EMF - a constant component of its Fourier-series expansion; this component does not create EMF, loads the magnetic core by raising its weight, increases the inductance of the armature winding and its inductive reactance and decreases the machine power. Therefore, a decrease in the constant component of magnetic flux can serve as a supplementary criterion of the IEM operational efficiency.

To raise the extent of using the magnetic flux in an IEM is the problem of basic importance. It is desirable that there is such a change in the tooth zone permeance (being in essence the permeance of its airgap), and, respectively, the armature winding magnetic-flux linkage that would provide the maximum first harmonic component, which determines the main EMF as well as the minimum zeroth component and the highest harmonic components.

Investigations in this direction (e.g., [1]-[3]) have embraced some part of possible shapes of rotor teeth - mainly a trapezoidal with curvatures in slots and a rectangular one. It is important to look at more recent investigation to different types of machines where possible shapes of rotor teeth are evaluated (e.g., [4]-[6]). Investigations have been carried out both analytically and by modelling. A major portion of possible tooth profiles have not been elucidated. Therefore, the present research gives determination of the harmonic series for the permeance of the IEM tooth zone airgap in order to widen the composition of rotor tooth profiles and their corresponding geometric parameters. Based on these considerations, the research provides estimation of the values and forms of armature winding EMF.

This investigation relates to the IEMs with rotor teeth evenly arranged along a recess.

\section{PROFILES OF ROTOR TEETH AND THEIR PARAMETERS}

By the character of airgap variations in the tooth zone along the recess the IEMs can be divided into two groups: whose zones have a section of rotor tooth pitch with a constant gap, and whose zones are without such a pitch - that is, their airgap is variable along the rotor tooth pitch. To the first group we can relate the IEMs having rectangular rotor teeth with parallel walls (Fig. 1, a), trapezoidal ones (Fig. 1, b), rectangular with curvatures (Fig. 1, c), of combined shape (Fig. 1, d) with the airgap uniform at the middle section, but at tooth edges changing in compliance with the cosecant law [7], [8]:

$$
\delta=\delta_{\min } \cdot \csc \left(b_{R}^{\circ}\right)=\frac{\delta_{\min }}{\sin \left(b_{R}^{\circ}\right)}
$$


Profiles of the 2nd group are considered in Section 5. The rectangular profile is most often encountered.

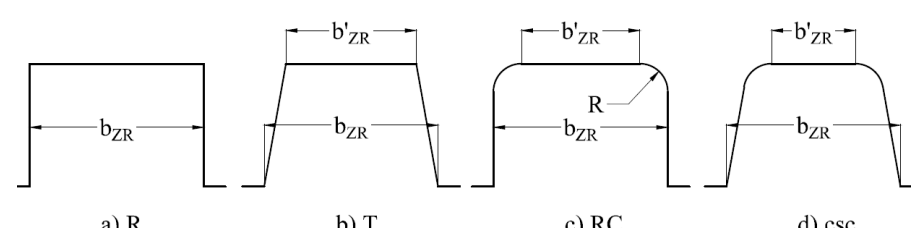

a) $\mathrm{R}$

b) $\mathrm{T}$

c) $\mathrm{RC}$

d) $\csc$

Fig. 1. Rotor tooth shapes with constant air gap.

Figure 2 shows a fragment (a) and a developed (b) view of a tooth zone with a rectangular tooth; geometric parameters indicated are the following:

a) $D_{S}, D_{R}, D_{P}$ - the diameter of stator, rotor and circumference across the rotor slot bottom;

b) $b_{S}\left(b_{R}\right), b_{Z S}\left(b_{Z R}\right), b_{P S}\left(b_{P R}\right)$ - the tooth pitch, the width of tooth $(Z)$, the width of slot $(P)$, for stator $(S)$ and $\operatorname{rotor}(R)$;

c) $b_{S}^{\circ}\left(b_{R}^{\circ}\right), b_{Z S}^{\circ}\left(b_{Z R}^{\circ}\right), b_{P S}^{\circ}\left(b_{P R}^{\circ}\right), b_{S}^{E}\left(b_{R}^{E}\right), b_{Z S}^{E}\left(b_{Z R}^{E}\right), b_{P S}^{E}\left(b_{P R}^{E}\right)-$ similar angular sizes in degrees $\left({ }^{\circ}\right)$ and electrical degrees $(E)$;

d) $h_{Z R}-$ the rotor tooth height;

e) $\delta_{\min }, \delta_{\max }-$ the minimum and maximum airgaps.

The parameters indicated above are determined by the formulas:

$$
\begin{aligned}
& b_{S}=\frac{\pi D_{S}}{Z_{S}} ; \quad b_{R}=\frac{\pi D_{R}}{Z_{R}} ; \quad b_{S}^{\circ}=\frac{360^{\circ}}{Z_{S}} ; \quad b_{R}^{\circ}=\frac{360^{\circ}}{Z_{R}} ; \\
& b_{Z S}^{E}=\frac{360^{\circ} b_{Z S}}{b_{R}} ; \quad b_{Z R}^{E}=\frac{360^{\circ} b_{Z R}}{b_{R}} ; \quad b_{P R}^{E}=b_{R}^{E}-b_{Z R}^{E},
\end{aligned}
$$

where $Z_{S}$ and $Z_{R}$ are the numbers of stator and rotor teeth.

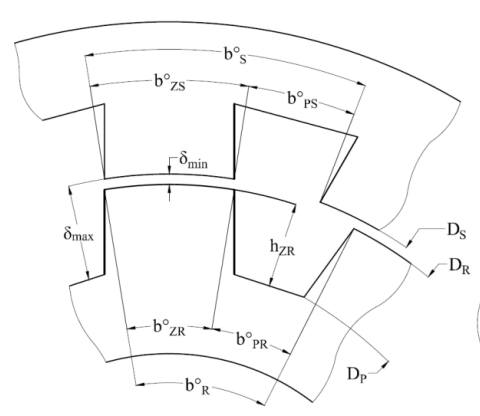

a)

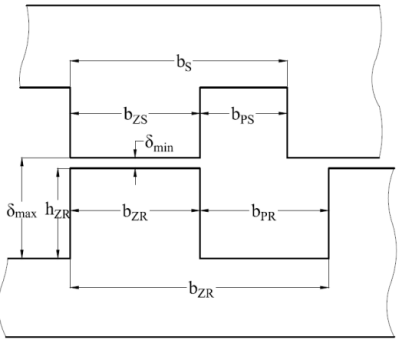

b)

Fig. 2. Tooth zone with a rectangular tooth fragment (a) and a developed view (b).

At investigation of tooth zones, the parameters $b_{Z S}(\mathrm{c})$ and $b_{Z R}\left(b_{Z R}^{\circ}\right)$ are to be varied in order to achieve the optimal result. It is more convenient to deal with the 
parameters expressed via the relation to the rotor tooth pitch $b_{R}$, e.g., $b_{Z S} / b_{R}=0.4$; $b_{Z R} / b_{R}=0.5$. Having omitted the designations in letters, a tooth zone might be conditionally designated as a sequence of cipher values (through a hyphen) of the mentioned relationships (for example, 0.4-0.5), with adding the designation of the tooth profile shape: $\mathrm{R}$ - rectangular; $\mathrm{T}$ - trapezoidal, $\mathrm{RC}$ - rectangular with curvature; $\mathrm{K}$ - cosecant, etc. For zones T, RC, and $\mathrm{K}$ between the $b_{Z S} / b_{R} ; b_{Z R} / b_{R}$ values it is necessary to add the ratio of width $b_{Z R}^{\prime}$ of the section with a uniform airgap (Fig. 1, b, $\mathrm{c}, \mathrm{d})$ to $k, b_{R}, B$. In such cases, the conditional designation cipher of the tooth zone will be: $0.4-0.3-0.5 R C$, i.e., $b_{Z S} / b_{R}=0.4 ; b_{Z R}^{\prime} / b_{R}=0.3 ; b_{Z R} / b_{R}=0.5$; the profile is rectangular with curvatures. All the mentioned aspects also relate to the corresponding angular sizes. Thus, zone $0.3-0.5 \mathrm{R}$ has $b_{Z S}^{E}=0.3 \cdot b_{R}^{E}=0.3 \cdot 360^{\circ}=108^{\circ}$; $b_{Z R}^{E}=0.5 \cdot b_{R}^{E}=0.5 \cdot 360==180^{\circ}$; the tooth is rectangular.

The most general - that is, suitable for the majority of IEMs of diversified specification - optimal tooth zone parameters according to recommendations [1] [3], [9]-[12] are:

$$
\begin{aligned}
& b_{Z S}\left(b_{Z R}\right)=(0.3 \div 0.4) b_{S}\left(b_{R}\right) ; b_{P R}=\left(\frac{2}{3} \div \frac{3}{5}\right) b_{R} ; \\
& h_{Z R} \leq 0.75 b_{P R} ; \delta=\left(\frac{1}{200} \div \frac{1}{300}\right) D_{R}
\end{aligned}
$$

The increase in $b_{Z S}^{E}>0.5 b_{S}$ is connected with the decrease in the width of slot for winding, the increase in the diameter of stator and the weight of machine. The decrease in the $b_{Z R}$ as compared with $b_{Z S}$ results in a decreasing permeance of the tooth zone and its effectiveness.

To ensure the identity of the investigation into tooth zones with different rotor tooth and slot profiles, a number of parameters should remain invariable; this refers to $b_{R} ; b_{S} ; h_{Z R} ; \delta ; D_{S} ; D_{R}$ as well as to the number of stator and rotor teeth, $Z_{S}$ and $Z_{R}$.

\section{THEORETICAL PREREQUISITES OF THE INVESTIGATION}

In the inductor machine at the displacement of a rotor tooth relative to a stator tooth, the permeance of airgap under the stator tooth changes, and, consequently, the magnetic flux and magnetic-flux linkage with the armature winding are also changing, and there is induced EMF with a period $T=2 \pi \mathrm{rad}$. (or $360^{\circ} \mathrm{el}$.). This means that the rotor tooth plays the role of a pole pair "p" of a common synchronous machine, i.e., in the IEM we will have $p=Z_{R}$ with the EMF frequency $f=\frac{Z_{R} n}{60}$
where $n$ - is the rotational speed, min $^{-1}$.

In order to achieve that in the tooth zone on the rotor tooth pitch $b_{R}\left(b_{R}^{\circ}\right)$ mutual overlapping would not occur by the rotor tooth of more than (even if partially) one stator tooth, the following condition must be fulfilled:

$$
b_{Z S}+b_{Z R} \leq b_{R} ; b_{Z S}^{\circ}+b_{Z R}^{\circ} \leq b_{R}^{\circ} ; b_{Z S}^{E}+b_{Z R}^{E} \leq b_{R}^{E} \text {. }
$$


As this takes place, for each pass of a rotor tooth relative to a stator tooth the required angle of rotor turning $\alpha^{\circ}$ is determined by parameters $b_{Z S}^{\circ} ; b_{Z R}^{\circ} ;\left(b_{Z S}^{E} ; b_{Z R}^{E}\right)$ and is equal to their sum, i.e.:

$$
\alpha^{\circ}=b_{Z S}^{\circ}+b_{Z R}^{\circ} ; \alpha^{E}=b_{Z S}^{E}+b_{Z R}^{E} \text {. }
$$

The sum $b_{Z S}^{\circ}+b_{Z R}^{\circ}$, which at mutual displacement of the rotor tooth relative to the stator tooth provides inducing the EMF with a period $T=360^{\circ}$, in the electrical designation is equivalent to $360^{\circ}$. Thus, in electrical units $\alpha^{E}=\alpha^{\circ} Z_{R}=360^{\circ}=2 \pi$.

Conditions (2) might be expressed in the form:

$$
\frac{b_{Z S}^{\circ}}{b_{R}^{\circ}}+\frac{b_{Z R}^{\circ}}{b_{R}^{\circ}} \leq 1 ; \frac{b_{Z S}^{E}}{b_{R}^{E}}+\frac{b_{Z R}^{E}}{b_{R}^{E}} \leq 1
$$

Conditions (2)-(5) determine possible combinations of parameters $b_{Z S}-b_{Z R}$; $b_{Z S}^{\circ}-b_{Z R}^{\circ} ; b_{Z S}^{E}-b_{Z R}^{E}$. Here a set of such variants can be composed, which in a designing point of view are executable both at $b_{Z S} \leq b_{Z R}$ and at $b_{Z S} \geq b_{Z R}$.

For the investigation purposes, having established a gradation of variations in the indicated sizes as $0.1 b_{R}\left(0.1 b_{R}^{E}\right)$, it is possible to restrict ourselves to the finite number of variants.

Thus, at $\frac{b_{Z S}}{b_{R}}=0.3$ the variants $\frac{b_{Z R}}{b_{R}}$ will be: $0.3 ; 0.4 ; 0.5 ; 0.6 ; 0.7$;

At $\frac{b_{Z S}}{b_{R}}=0.4$ these variants will be: $0.3 ; 0.4 ; 0.5 ; 0.6$;

At $\frac{b_{Z S}}{b_{R}}=0.5$ these variant will be: 0.5 .

This means that at its known (selected, calculated) value, $b_{Z S} \quad\left(b_{Z S}^{E}\right)$ determines the variant of combination $b_{R S}\left(b_{R S}^{E}\right)$ as $b_{Z R} \leq b_{R}-b_{Z S}$ or $b_{Z R}^{E} \leq b_{R}^{E}-b_{Z S}^{E}$ shown in (7).

During the period corresponding to the sum $b_{Z S}^{E}+b_{Z R}^{E}$ displacement occurs of a rotor tooth relative to a stator tooth as well as relevant variations in the airgap permeance, flux, magnetic-flux linkage with the armature winding and in the induced there EMF. Therefore, this period and the corresponding angle $\gamma_{P}^{E}$ could be conditionally named "operational", while from expression (4) it follows that $\gamma_{P}^{E}=b_{Z S}^{E}+b_{Z R}^{E}$.

In passing of a rotor slot relative to a stator tooth, changes mentioned above and inducing EMF do not practically occur; therefore, this time interval and the relevant angle $\gamma_{x}^{E}$ can be conditionally named "idle run" while $\gamma_{x}^{E}=b_{R}^{E}-\gamma_{P}^{E}$. The greater the working time is, the higher the efficiency of IEM operation. The maximum efficiency will be at $\gamma_{x}^{E}=0$ and $b_{Z S}^{E}=b_{Z R}^{E}=180^{\circ}$ which corresponds to the zone $0.5-0.5$. However, these assumptions need verification. 
The airgap between stator and rotor in the rotor tooth pitch $b_{R}\left(b_{R}^{E}\right)$ along $D_{S}$ is determined by the tooth and slot profiles, and in the range of the profiles under consideration (7) is not unambiguous. Thus, even in the simplest by configuration profile of rotor tooth, i.e., rectangular with the associated trapezoidal slot (Fig. 1, a) the airgap is varying from the minimum $\delta_{\min }$ in $b_{Z R}$ limits up to the maximum $\delta_{\max }$ in $b_{P R}$ limiting values, and differs for different $b_{R}\left(b_{R}^{E}\right)$ values. This presents definite difficulties at establishment of the rule of airgap permeance variations, which would allow for its determination in any point of a tooth pitch $b_{R}\left(b_{R}^{E}\right)$.

It would be worthwhile to replace the line of investigation into the tooth and slot profiles by a step-wise one, having broken up these profiles in the tooth pitch into a series of equal by width (angle) elementary sections $\Delta b_{R}\left(\Delta b_{R}^{E}\right)$ (Fig. 2). The height of the elementary section between the line of $D_{S}$ and the line of profiles will appear as the airgap value for this section. In this case, either $\Delta b_{R}$ or $\left(\Delta b_{R}^{E}\right)$ value is selected and the number $\chi$ of elementary sections is determined:

$$
\chi=\frac{b_{R}}{\Delta b_{R}}=\frac{\pi D_{R}}{Z_{R} \Delta b_{R}} ; \chi=\frac{b_{R}^{E}}{\Delta b_{R}^{E}}=\frac{360^{\circ}}{\Delta b_{R}^{E}} .
$$

Vice versa, with the number $\chi$ defined, the values $\Delta b_{R}, \Delta b_{R}^{\circ}, \Delta b_{R}^{E}$ are determined (the last one in el. degrees). To all the sections index numbers are assigned: $i=1,2,3, \ldots, \chi$ the corresponding airgaps will be numbered similarly $\delta_{i}$. The specific airgap permeance corresponding to the $i$-th section $\Delta b_{R i}\left(\Delta b_{R i}^{E}\right)$ can be determined as in [8]:

$$
\lambda_{i}=\frac{S_{i} \mu_{0}}{\delta_{i}}=\frac{\Delta b_{R i} l \mu_{0}}{\delta_{i}}
$$

where $S_{i} ; \Delta b_{R i} ; l$ are the aria, width, and axial length of elementary section, $\mu_{0}$ is the magnetic permeability of vacuum.

When using formula (9) it is necessary to meet the following conditions:

$$
\frac{\delta_{i}}{\Delta b_{R i}} \leq 0.04 ; \frac{\delta_{i}}{l} \leq 0.04 \text {, which would ensure the error not greater than } 10 \% \text {. }
$$

Since $S_{i}, \Delta b_{R i}, l, \mu_{0}$ are constant values and do not depend on whether or not the rotor is running, assuming the product $\Delta b_{R i} l \mu_{0}$ to be equal to an arbitrary unit, we will obtain the expression for specific permeance of the elementary profile section in arbitrary units of magnetic permeance in the form:

$$
\lambda_{i}=\frac{1}{\delta_{i}}
$$

where the $\delta_{i}$ value can be determined from the sketch of developed view of the machine tooth zone (Fig. 2) or, otherwise, calculated.

The magnetic flux through the elementary section square $S_{i}$ is $\Phi_{i}=F \cdot \lambda_{i}$, 
and at choosing the MMF of $F$ excitation equal to the MMF arbitrary unit $(F=1)$ the flux can be determined in the arbitrary units for flux as $\Phi_{i}=\lambda_{i}$.

The magnetic induction in the elementary section is $B_{i}=\frac{\Phi_{i}}{S_{i}}$ and, since $S_{i}=$ const. , then, having assumed $S_{i}$ as being equal to one arbitrary unit for square, we will obtain this induction in arbitrary units for induction, i.e., $B_{i}=\lambda_{i}$.

The magnetic-flux linkage $\Psi_{i}$ of the armature winding coil due to the elementary section flux is $\Psi_{i}=\Phi_{i} \cdot W_{C}$ taking the number of coil turns $W_{C}$ equal to one arbitrary unit for turns, we can consider $\Psi_{i}$ in arbitrary units for magnetic-flux linkage, i.e., $\Psi_{i}=\lambda_{i}$.

\section{ANALYSIS OF THE ROTOR TOOTH SHAPES}

All the aspects highlighted above determine the methods for investigation that can be used at definite values of the input parameters $D_{S}, D_{R}, D_{P}, b_{R}\left(b_{R}^{o}, b_{E}^{o}\right)$, $b_{Z S}^{o}, b_{Z R}^{o}, h_{Z R}, \delta_{\text {min }}$, as well as $Z_{R}$ and $Z_{S}$ that are chosen or calculated preliminarily.

For example, EMF $e_{1}$ of the first harmonic component of magnetic-flux linkage $\Psi_{1}=a_{1} \cos \alpha^{E}$ will be determined as

$$
e_{1}=-\frac{d \Psi_{1}}{d t}=-\frac{d}{d t}\left(a_{1} \cos \alpha^{E}\right)=-\frac{d}{d t}\left(a_{1} \cos \omega Z_{R} t\right)=a_{1} \omega Z_{R} \sin \alpha^{E}
$$

The EMFs of other harmonic components of magnetic-flux linkage are determined similarly; thus, in general form the expression for machine EMF will be:

$$
e\left(\alpha^{E}\right)= \pm a_{1} \sin \alpha^{E} \pm 2 a_{2} \sin 2 \alpha^{E} \pm \ldots \pm k a_{k} \sin k \alpha^{E}=\sum_{k=1}^{n} k a_{k} \sin \left(k \alpha^{E}\right) \text {, }
$$

where $k$ is the EMF harmonic component number $(k=1,2,3, \ldots)$.

By using the investigation algorithm that would be inverse of the considered in Section 3, it is possible - assuming the $\Psi(\omega t)$ variations - to carry out synthesis of tooth and slot profiles.

To compare analytically obtained results, where most calculations are done according to [13], [14] recommendations, the FEA simulations are done using computer software Flux 2D by Cedrat Reaserch [15]. FEA method is well established and in-depth description is available in many sources. In contrast to analytical method, FEA method takes into account magnetic saturation. Magnetic saturation has profound influence on armature EMF sinusodiallity [6], [16].

The whole node number of the model under investigation is about 10000 . The simulation is carried out as magneto-static application where movement of rotor by angle $\alpha$ is imposed for full pole pitch $b_{R}^{E}=360^{\circ}$ el. Calculation step is chosen as $\Delta \alpha^{E}=0.5^{\circ}$. In contrast to the analytical method, the geometry of model is defined in metric units. Magnetizing force is defined to such a value that yields saturation of iron core just below a saturation point. Figure 3 shows the results obtained for magnetic field density in $\mathrm{T}$. 


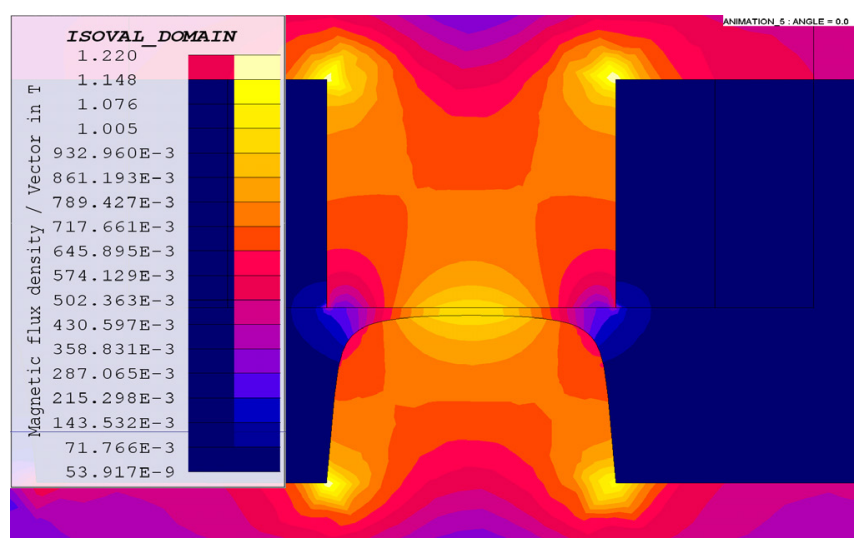

Fig. 3. Magnetic field density for $0.5-0.5 \csc \left(b_{R}^{\circ}\right)$ at $\alpha^{E}=180^{\circ}$.

Through FEA studies, using in software built-in tools, alternating flux linked with the winding can be obtained. EMF induced in coil can be found by derivative of alternating flux over time $E M F=-W_{C} \frac{d \Phi}{d t}$, where turn number $W_{C}=1$ is assumed. Machine rotation speed is not defined within the framework of research, therefore derivative over angle $\alpha^{E}$ is used $\frac{d \Phi}{d \alpha^{E}}$ in $\frac{W b}{d e g}$ with respect to $E M F=K \frac{d \Phi}{d \alpha^{E}}$, where $\mathrm{K}$ - the coefficient describing relationship between machine rotation speed and angle $\alpha^{E}$. Previous research shows applicability of FEA method to EMF harmonic content analysis [16].

\section{TOOTH ZONES WITH NONUNIFORM AIRGAP}

Figure 4 gives fragments of tooth zones with nonuniform airgap on the rotor tooth pitch: (a) - a tooth zone $0.5-0.5 \mathrm{~K} 1$, with the airgap spread along the rotor tooth width as $\delta=\delta_{\min } \cdot \csc \left(b_{R}^{\circ}\right), \delta_{\min }=1, h_{Z R}=22, \delta_{\max }=23$; (b) - a tooth zone $0.5-0.5 S$, with the airgap spread along as $\delta=2-\sin \left(b_{R}^{\circ}\right), \delta_{\min }=1, h_{Z R}=22$, $\delta_{\max }=2$; (c) Fig. 4,c - a tooth zone $0.5-0.5 \mathrm{~K}$ with the tooth of wedge shape, $\delta_{\text {min }}=1, \delta_{\max }=1.5$.

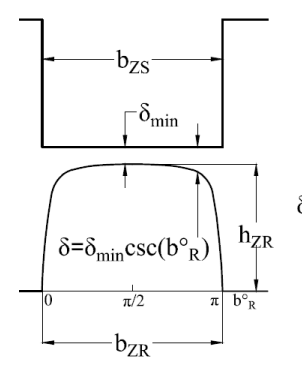

a) $\mathrm{K} 1$

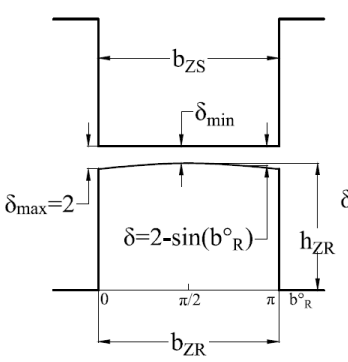

b) $\mathrm{S}$

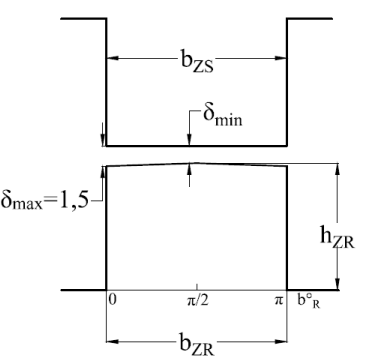

c) $\mathrm{K}$

Fig. 4. Fragments of rotor tooth zones with nonuniform airgap. 
The results of investigation into such tooth zones are presented in Table 1. As criteria of IEM efficiency at its operation with one or other rotor tooth profile given in Table 1 the following ones are used: $\frac{E_{1}}{E} \%$ - the ratio of operating EMFs of the first harmonic $E_{1}$ to the overall EMF of armature winding $E$ expressed in percent;

$\frac{E_{i}}{E} \%$ - the ratio of operating highest EMF harmonics $E_{i}$ to the overall EMF of armature winding $E$ expressed in percent, where $i=2,3, \ldots, 5$;

$$
T H D=\frac{\sqrt{\sum_{i=2}^{15} E_{i}^{2}}}{E_{1}}-\text { the total harmonic distortion (THD), where first } 15 \text { harmonics }
$$

are taken into account, to the first harmonic $E_{1}$ expressed in percent.

In the graphic form the results of investigation are presented in Fig. 7. If we compare the factors pointing to the influence exerted by rotor tooth profiles on the value and shape of the armature winding EMF reported in [1]-[3] with those obtained in the given investigation, it could be seen that the results are practically identical for the profiles considered in the mentioned sources, and can therefore serve as a criterion of confidence in the results of our investigation into the whole set of rotor tooth profiles using the methods proposed in the present research.

\section{ANALYTICAL TREATMENT OF THE INVESTIGATION RESULTS FOR THE IEM TOOTH ZONES}

Based on the results of investigation into the IEM tooth zones, the following conclusions can be drawn:

1) Tooth zones with unequal values $b_{Z S}^{E}$ and $b_{Z R}^{E}$ (e.g. 0.4-0.5T) - when the conditions $b_{Z S}^{E}+b_{Z R}^{E} \leq b_{R}^{E}$ are observed - have on the corresponding graphs $\Psi\left(\alpha^{E}\right)$ (Fig. 5) the sections (shelves) with constant magnetic-flux linkage, in the range of whose values $\alpha^{E}$ no EMF in the armature winding is induced, this reduces the overall winding EMF and the effectiveness of using such "asymmetrical" tooth zones.

2) The mentioned circumstance is a validation of presumption that has been considered in Section 2 as to the negative influence on the effectiveness of a tooth zone exerted by its "idle run" $\gamma_{x}^{E}=\gamma^{E}-\left(b_{Z S}^{E}+b_{Z R}^{E}\right)$ - the greater the $\gamma_{x}^{E}$, the lower the EMF value for the given group of tooth zones (Fig. 5).

3) Similar effect is also observed for tooth zones with equal $b_{Z S}^{E} ; b_{Z R}^{E}$ values, e.g., 0.3-0.3R and 0.4-0.4R. This effect manifests itself in a decreased amplitude on the corresponding graph $\Psi\left(\alpha^{E}\right)$ and in a decreased induced EMF (Fig. 5).

4) The highest in effectiveness EMF is for the tooth zone $0.5-0.5 \mathrm{R}$ in which the "idle run" $\gamma_{x}^{E}=0$ is theoretically absent, so the whole time of rotor tooth passing under stator tooth is operating $\gamma_{P}^{E}=\left(b_{Z S}^{E}+b_{Z R}^{E}\right)$; this circumstance validates the presumption about the highest in effectiveness EMF for the tooth zone with $b_{Z S}^{E}=b_{Z R}^{E}=180^{\circ}$.

5) By analytical calculations the minimum content of the highest harmonic EMFs is provided by the tooth zone $0.5-0.5 \csc \left(b_{R}^{\circ}\right)$ (Table 1$)$, in which the uneven 
airgap on the $b_{R}^{\circ}$ rotor pitch is spread by the cosec law (3) in the range $b_{R}^{\circ}=0 \div 180^{\circ}$. A machine with such a tooth zone has the EMF shape close to sinusoid (Fig. 7).

6) By FEA calculations the minimum content of the highest harmonic EMFs is provided by the tooth zone $0.5-0.5 \sin \left(b_{R}^{\circ}\right)$ (Table 1$)$. A machine with such a tooth zone has the EMF shape close to sinusoid (Fig. 7).

7) As a consequence, the generators made based on the use of tooth zone $0.5-0.5 \sin \left(b_{R}^{\circ}\right)$ fulfil EN 50160 standard [17] criteria on most terms and with minor improvements may be applied for direct connection to the grid, without using additional intermediate convertors (Table 1).

8) Difference between analytical calculations and FEA calculations (Fig. 6) are due to magnetic steel saturation (Fig. 4) and assumed simplifications for analytical calculations. The magnetic field lines are bent in the air gap as shown in Fig. 8, where analytical calculations do not take this effect into account. For conventional electrical machine design, coefficients are used to take this effect into account.

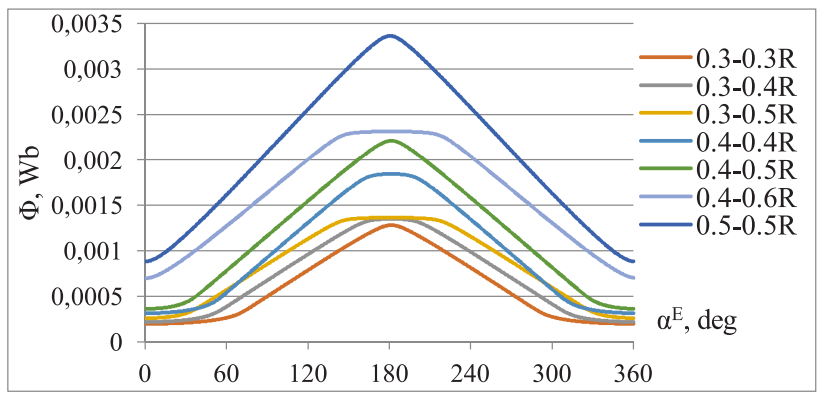

Fig. 5. Magnetic flux for rectangular shaped teeth.

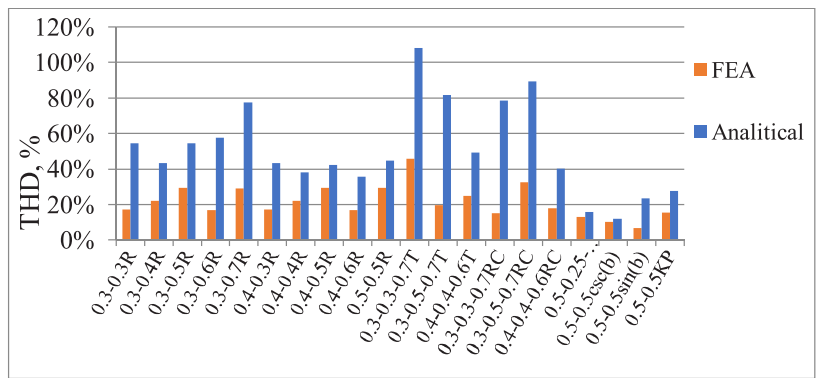

Fig. 6. EMF total harmonic distortion for analytically calculated and finite element results.

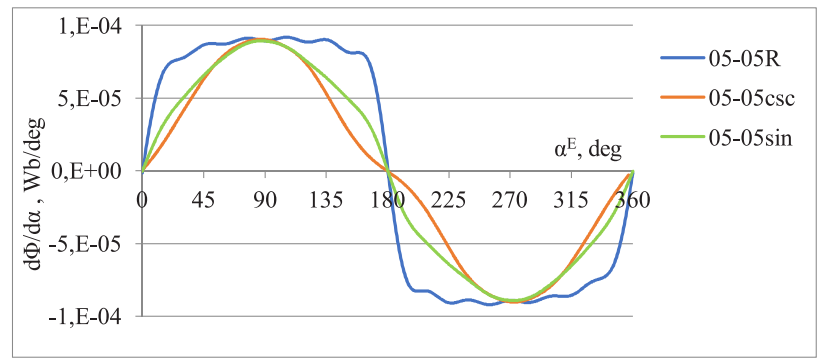

Fig. 7. $\frac{d \Phi}{d \alpha}$ shape that indicates EMF shape. 
EMF Harmonic Content Data for Chosen Rotor Tooth Profiles

\begin{tabular}{|c|c|c|c|c|c|c|c|c|}
\hline \multirow[b]{2}{*}{ Tooth profile } & \multirow{2}{*}{$\begin{array}{c}\text { Analy- } \\
\text { tical }\end{array}$} & \multirow{2}{*}{$\begin{array}{c}\text { FEA } \\
T H D \\
\%\end{array}$} & \multirow{2}{*}{$\begin{array}{c}E_{l} / E \\
\%\end{array}$} & \multirow{2}{*}{$\begin{array}{c}\frac{d \Phi}{d \alpha} \\
W b / d e g\end{array}$} & \multicolumn{4}{|c|}{ Harmonic content to fundamental } \\
\hline & & & & & $\begin{array}{c}E_{2}, \\
\%\end{array}$ & $\begin{array}{c}E_{3}, \\
\%\end{array}$ & $\begin{array}{c}E_{4} \\
\%\end{array}$ & $\begin{array}{c}E_{5}, \\
\%\end{array}$ \\
\hline $0.5-0.5 R$ & $44.0 \%$ & $29.6 \%$ & $95.8 \%$ & $7.76 \cdot 10^{-5}$ & $2.55 \%$ & $25.40 \%$ & $1.68 \%$ & $11.92 \%$ \\
\hline $0.5-0.5 \csc \left(b_{R}^{\circ}\right)$ & $11.9 \%$ & $10.2 \%$ & $99.5 \%$ & $6.06 \cdot 10^{-5}$ & $5.70 \%$ & $7.64 \%$ & $1.77 \%$ & $3.02 \%$ \\
\hline $0.5-0.5 \sin \left(b_{R}^{\circ}\right)$ & $23.4 \%$ & $6.9 \%$ & $99.7 \%$ & $6.44 \cdot 10^{-5}$ & $0.28 \%$ & $4.97 \%$ & $1.15 \%$ & $4.11 \%$ \\
\hline EN 50160 & $8 \%$ & $8 \%$ & - & - & $2 \%$ & $5 \%$ & $1 \%$ & $6 \%$ \\
\hline
\end{tabular}

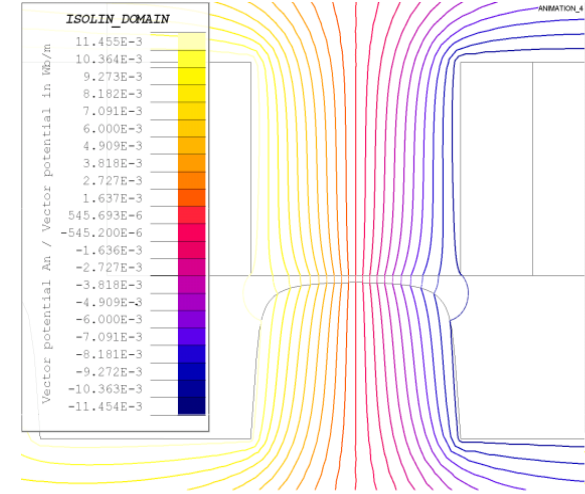

a)

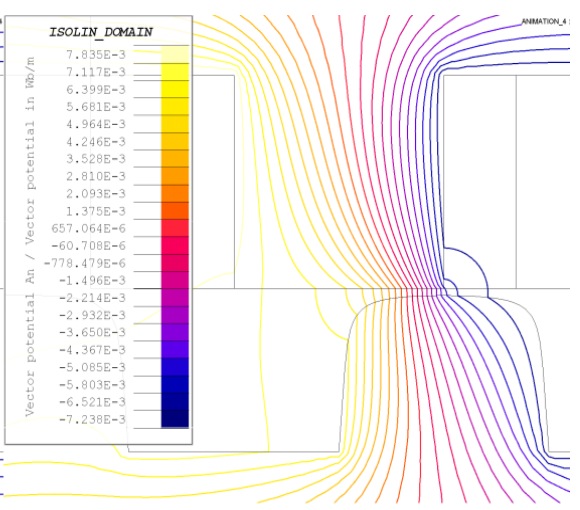

b)

Fig. 8. Magnetic field vector potential for $0.5-0.5 \csc \left(b_{R}^{\circ}\right)$ (a) $\alpha^{E}=180^{\circ}$ (b) $\alpha^{E}=270^{\circ}$.

\section{CONCLUSIONS}

Depending on the configuration of rotor teeth and slots and the relationships between their geometric parameters more than 20 types of IEM tooth zones have been investigated. The main criteria that determine the effectiveness of using these zones have been established. Zones that are optimal from the viewpoints of the maximum armature winding EMF and the minimum content of its highest harmonic components have been revealed. The possibility of using the inductor generators for direct connection to the grid has been shown. Recommendations as to the practical use of the investigation results have been given.

Further optimization for rotor tooth shape can be done taking into account the established magnetic field line path in the airgap. For further analysis FEA calculations should be used. Coil end connection influence on higher harmonic content has not been taken into account in the study. Three-dimensional finite element analysis can be performed to set dependencies for higher harmonic content to coil end connections. 


\section{ACKNOWLEDGEMENTS}

The research has been developed within the framework of Doctoral studies grant of Riga Technical University.

\section{REFERENCES}

1. Zhezherin, R. (1961). Inductor generators. Moscow: GEI (in Russian).

2. Aleksejeva, M. M. (1967). Machine generators with increased frequencies. Latvia: Energija.

3. Dombur, L. E. (1984). Axial inductor generators. Riga: Zinatne.

4. Steven, A. E. (2010). Salient pole shoe shapes of interior permanent magnet synchronous machines. In 2010 XIX International Conference on Electrical Machines (ICEM), Rome, Italy: IEEE.

5. Deaconu, S. I., Tulelea, L., Popa, G. N., Popa, I., \& Abrudean, C. (2008). Optimizing the design of a reactive homopolar synchronous machine with stator excitation. Industrial Electronics, 2008. IECON 2008. 34th Annual Conference of IEEE, Orlando, FL, USA: IEEE.

6. Kutt, F., Michna, M., Kostro, G., Ronkowski, M., \& Adamczyk, D. (2014). Synchronous generator model taking into account the non-uniform saturation of the pole shoes. In 2014 International Conference on Electrical Machines (ICEM), Berlin: IEEE.

7. Boldea, I. (2006). Synchronous generators. Boca Raton, FL: CRC Press.

8. Pyrhönen, J., Jokinen, T., \& Hrabovcova, V. (2008). Design of rotating electrical machines. Chichester: John Wiley \& Sons, Ltd.

9. Santalov, A. M., \& Serebryakov, A.D. (1976). On the optimal geometry of the tooth zone of inductor machines. In Proceedings of RKIIGA (Vol. 113, pp. 12-23). Riga (in Russian).

10. Levin, N. N., \& Serebrjakov, A. D. (1976). Electrical machines and devices. Riga.

11. Serebrjakov, A. D. (1982). Optimal tooth zone of inductor motor-Brushless electrical machines. Riga: Zinatne.

12. Levin, N. N., \& Serebrjakov, A. D. (1974).Tooth zone parameter influence on speed of response for motionless electrical motor. Riga.

13. Buls, B.K. (1964). The basics of theory and calculations for magnetic field. Moscow: Energija.

14. Bronstein, I. N. (1957). Handbook of mathematics. Moscow: Gostekhizdat.

15. Flux2D software, (2016). [Online]. Available at http://www.cedrat.com.

16. Gulbis, K., \& Kamolins, E. (2017). Investigation of synchronous inductor generator with electrically integrated armature and excitation windings for AC and DC power supply. In 58th International Scientific Conference on Power and Electrical Engineering of Riga Technical University (RTUCON), Riga, Latvia: IEEE.

17. EN 50160:2010, (2010). Voltage characteristics of electricity supplied by public electricity networks. 


\title{
INDUKTORMAŠĪNAS ZOBU ZONAS EFEKTIVITĀTE
}

\author{
A. Serebrjakovs, E. Kamoliņš, K. Gulbis, K. Sējējs
}

Kopsavilkums

Autori apskata vairākus desmitus induktormašīnu rotora zobu un rievu formas, lai tiktu sasniegta maksimālā enkura tinuma EDS vērtība ar minimālu augstāko harmoniku saturu, kā rezultātā iespējams palielināt mašīnas īpatnējo jaudu un lietderības koeficientu.

Pētījuma ietvaros aprēķini tiek veikti ar analītisku metodi un galīgo elementu metodi, kur galīgo elementu metode ņem vērā gan elektrotehniskā tērauda magnētisko piesātinājumu, gan magnētiskā lauka līniju sadalījumu. Abu aprēķinu galvenie dati ir apkopoti pētījuma rezultātos. No iegūtajiem rezultātiem var secināt, ka vairumā gadījumu analītiskā metode nav pielietojama kvalitatīvai EDS augstāko harmoniku sastāva noteikšanai, jo magnētiskā lauka līnijas plaknē nenoslēdzas paralēli un to sadalījums ir tieši saistīts ar zobu zonas konfigurāciju.

Pētījuma rezultāti parāda, ka induktorǵeneratorus ir iespējams izmantot tiešai pieslēgšanai pie energoapgādes tīkla.

18.05.2018. 